\author{
Birillo Inna \\ candidate of engineering sciences \\ Associate Professor of the Department of arts \\ Kyiv University of Culture \\ ORCID 0000-0002-2690-9621 \\ In.Birillo@i.ua \\ Vovk Liudmyla \\ Candidate of Physical and Mathematical Sciences, \\ Associate Professor of the Department of \\ International Relations, \\ Kyiv University of Culture \\ ORCID 0000-0001-8067-3640 \\ ludmylavera@gmail.com
}

\title{
ORGANIZATION OF PROJECT ACTIVITY
}

The purpose of the article. The main purpose of this research is to reveal the features of the subject "Organization of the project activity" in the process of training future architects and designers in higher education institutions. The methodology of the research consists in application of general scientific methods (analysis, synthesis, comparison, and generalization, systematization, classification), empirical methods (observation, questioning, testing, questioning, a discussion in the process of conducting conversations, discussions with teachers and students, studying educational programs). It is based on theoretical positions, in which the project activity is considered not only as artistic, designer activity, but also as a unique set of coordinated works of a given content with a definite life cycle, alternative cost of resources, aimed at achieving the goals in the characteristics of duration and cost. Scientific novelty consists in elucidating the specifics of the organization of the project activity in the preparation of future architects and designers in higher education institutions. Conclusions. During the study of the discipline "Organization of project activity", future architects and designers, developing an architectural design project from the concept, ideas to its successful implementation, provide a systematic link between the fundamental theoretical training of students and their practical activities in the current market conditions of life. Applying the principles of an integrated approach to Architectural Graphic Design with using the toolkit for project analysis in its own project activities and having professional competencies, future specialists will become the most demanded and competitive on the modern labor market.

Keywords: project; project activity; training of specialists; architectural and design education.

Бірілло Інна Валеріївна, кандидат технічних наук, доцент кафедри мистецтв Київського університету культури; Вовк Людмила Василівна, кандидат фрізико-математичних наук, доцент кафредри міжнародних відносин Київського університету культури

\section{Організація проектної діяльності}

Метою роботи є розкриття особливостей дисципліни «Організація проектної діяльності» при підготовці майбутніх архітекторів та дизайнерів у закладах вищої освіти. Методологія дослідження полягає в застосуванні загальнонаукових методів (аналіз, синтез, порівняння та узагальнення, систематизація, класифікація), емпіричних методів (спостереження, опитування, тестування, анкетування, обговорення у процесі проведення бесід, дискусій із викладачами та студентами, вивчення навчальних програм), й ґрунтується на теоретичних положеннях, в яких проектна діяльність розглядається не тільки як мистецька, дизайнерська діяльність, а як унікальний набір скоординованих робіт заданого змісту з визначеним життєвим циклом, альтернативною вартістю ресурсів, що спрямовані на досягнення запланованих цілей у характеристиках тривалості та вартості. Наукова новизна полягає в з'ясуванні специфіки організації проектної діяльності при підготовці майбутніх архітекторів та дизайнерів у закладах вищої освіти. Висновки. Під час вивчення дисципліни «Організація проектної діяльності», майбутні архітектори та дизайнери, розробляючи архітектурно-дизайнерський проект від концепції, ідеї до його успішної реалізації, забезпечують системний зв'язок між фундаментальною теоретичною підготовкою студентів і їхньою практичною діяльністю у сучасних ринкових умовах життєдіяльності. Застосовуючи принципи комплексного підходу до архітектурно-дизайнерського проектування 3 використанням інструментарію аналізу проектів у власній проектній діяльності, володіючи фаховими компетентностями, майбутні фахівці стануть найбільш затребуваними та конкурентоспроможними на сучасному ринку праці.

Ключові слова: проект; проектна діяльність; підготовка фахівців; архітектурно-дизайнерська освіта.

Бирилло Инна Валерьевна, кандидат технических наук, доцент кафедры искусств Киевского университета культуры; Вовк Людмила Васильевна, кандидат фризико-математических наук, доцент кафедры международных отношений Киевского университета культуры

Организация проектной деятельности

Целью работы является раскрытие особенностей дисциплины «Организация проектной деятельности» при подготовке будущих архитекторов и дизайнеров в учреждениях высшего образования. Методология исследования заключается в применении общенаучных методов (анализ, синтез, сравнение и обобщение, систематизация, классификация), эмпирических методов (наблюдение, опрос, тестирование, анкетирование, обсуждения в процессе проведения бесед, дискуссий с преподавателями и студентами, изучение учебных программ), и основывается на теоретических положениях, в которых проектная деятельность рассматривается не только как художественная, дизайнерская деятельность, а как уникальный набор скоординированных работ заданного содержания с определенным жизненным циклом, альтернативной стоимостью ресурсов, направленных на достижение запланированных целей в характеристиках продолжительности и стоимости. Научная новизна заключается в выяснении специфики организации проектной деятельности при подготовке будущих архитекторов и дизайнеров в учреждениях высшего образования. Выводы. При изучении дисциплины «Организация проектной деятельности», будущие архитекторы и дизайнеры, разрабатывая архитектурно-дизайнерский проект от концепции, идеи к его успешной реализации, обеспечивают системную связь между фундаментальной теоретической подготовкой студентов и их практической деятельностью в современных рыночных условиях жизнедеятельности. Применяя принципы комплексного подхода к архитектурнодизайнерскому проектированию с использованием инструментария анализа проектов в своей проектной деятельности, обладая профессиональными компетенциями, будущие специалисты станут наиболее востребованными и конкурентоспособными на современном рынке труда.

(C) Birillo I., 2019

(C) Vovk L., 2019 
Ключевые слова: проект; проектная деятельность; подготовка специалистов; архитектурно-дизайнерское образова-

ние.

Introduction. The present stage of society development is characterized by a high degree of instability of the socio-economic sphere, which requires higher education institutions to prepare a professionally competent specialist capable of self-improvement, reflections of professional experience, competitive in the labor market. It should be with the ability to make non-standard decisions in various situations of professional activity, to choose effective scientific and practical tools for achieving the goal [1].

Analyzing the situation in Ukrainian universities, one can identify a number of problems that negatively affect the quality of architectural and design education, namely: The discrepancy of the content of education with the requirements of the present; Insufficient attention to the development of innovative forms and methods of professional training and its teaching and methodological support; Lack of conditions for complex educational and research projects; Insufficient level of motivation of students for educational and research activity, etc.

The problems outlined tend to aggravate in the process of professional training of future architects and designers since the formation of students of a complex of professional competencies takes place in a limited academic time.

Experience shows that in the educational process it is difficult to simulate all stages of the design, complete cycle of the project. Taking into account, in addition to the sequence of "issue of a task - a clause a sketch - submission of the project", as well as pre-design studies, the stage of the project and the working project, as well as project coordination and examination of project documentation, author's supervision, etc. When doing the project, the student rarely contemplates the cost of designing. Starting to work independently, the young architect or designer, for the most part, is difficult to predict the feasibility and effectiveness of the project, taking into account the range of risks that accompany the process.

As the research shows, in European countries [2] the organization of project activities in the training of future architects and designers includes not only creative and narrow technical tasks but also socioeconomic, turning a design into an integrated process. It is important to assess the financial and economic benefits of the project, to analyze its viability, to establish the value of the project, to evaluate the alternative cost of resources, and so on. The project activity involves not only a comprehensive study of the problem and the development of a particular product but above all, obtaining a practical result with all qualitative and quantitative benefits. Project activity is considered as controlled and modelized changes in the initial state of the object, associated with the optimization of intangible and material resources.

As the educational process is directed at the training of highly qualified specialists and the development of their creative abilities, finding opportunities to improve the efficiency and quality of the learning process through the implementation of modern of organizing project activities methods that meet the requirements of the time is timely and timely.

Therefore, the purpose of the publication is to disclose the features of the discipline "Organization of the project activity" in the preparation of future architects and designers.

Analysis of recent research and publications. Modernization of higher architectural design education in Ukraine is given due attention in the theory and practice of building university education, which is reflected in relevant publications: monographs, textbooks, articles, reports at conferences and seminars, etc. Various theoretical and methodological aspects of the preparation of architects and designers in the system of higher education are devoted to the study of BarkhinaM.G., Ezhova V.I., Yakovleva M.I., Kovaleva Y.M., and the others. In their research, the above scientists consider theoretical aspects and educational and methodological foundations of architectural and design education, the methodology of creative learning, study architecture education abroad, develop specific methods of architectural and artistic education [3-5].

E. Karpov reflects the problem of the use of design and technological activities in the research [6], where the author defines the method of projects as an educational technology, aimed at gaining new knowledge in the educational process in close connection with real-life practices.

The publication [7] presents the main stages and methods of preparing business plans of projects adopted in Ukraine and world practice with the ability to independently develop and analyze projects of different types.

Theoretical foundations of the research. The modern concept of "project" is multifaceted and meaningful. Domestic design practice, as a rule, related to research, design and architectural and construction activities, as the project meant a set of documents, calculations, drawings, necessary for the creation of any products or structures. The modern interpretation of the project goes beyond the above limits and, in the broadest sense, includes all types of activities ranging from conception, implementation of ideas and development of objects to their successful implementation.

On the one hand, the project is motivated (based on personal interest), purposeful (for a certain purpose or problem) voluntary, active, creative and research activity of the person [8]. On the other hand, the organization of design studies in modern realities of scientific and technological and technological progress, technology development, innovation, start-ups translates the view on the project as a controlled change in the initial state of any system related to tangible and intangible resources. Accordingly, the project is a com- 
bination of consistent, focused, interrelated actions aimed at achieving a clearly defined result in the conditions of limited resources: financial, raw material, human, temporal, etc.

Since the project is a format for the activities of a modern person, activities can be considered as a project only when: it objectively has a complex nature, and an analysis of the internal structure of the whole complex of works is important for determining its effectiveness; the transition from one type of work to another defines its main content; achievement of the goals of the activity is related to the equivalently sequential parallel execution of the components of these goals; time constraints, financial, material and labor resources are of particular importance in the process of carrying out the planned work; the duration and cost of the activity depending on the organization of the whole complex of works.

The main criteria for rejecting project ideas are insufficient demand for the proposed product obtained because of the project implementation; high project cost compared to expected revenue; technology not suitable for project implementation; an excessive scale of the project; excessive risk of project and others.

The main features of the project are:

1. Availability of innovations, the introduction of modern technologies, original ideas.

2. Availability of investments.

3. Availability of the project life cycle.

4. Optimizing the use of resources.

5. Functionality in a certain external environment, the presence of the internal environment.

Thus, the features of SMART projects [9] are concreteness, measurability, ability to achieve, resource realism, timeliness, specificity, measurable, achievable, realistic, and timely.

The main difference between an innovative project and a typical one is the need to address a large number of non-standard tasks, the adoption of original solutions. Today, innovation in the globalized world plays a key role. Unfortunately, in Ukraine, spontaneity in the processes of creation and implementation of innovations, lack of clear target orientation of innovations is observed [10-11].

The indispensable feature of innovation is the scientific and technical novelty, because of the development of technology - the main driving force of progress. New technology arises not only one, but in conjunction with other complementary technologies. Today, without the use of innovations it is almost impossible to create competitive products.

The term "innovation" literally means "investment in innovation" because of the practical mastering of a new process, technology, product or service. This is an explicit innovation, the implementation of a new idea, the introduction of a new method, approach or the use of new tools. Innovations are an effective means of competition, as they lead to the development of new markets, lower cost of products or services, an inflow of investments, enhance the image of the manufacturer.

Accordingly, the integral competence of designers, architects is the ability to solve complex problems and problems in the field of professional activity, which involves conducting research and implementation of innovations and characterized by uncertainty of conditions and requirements.

The concept of a project in modern business activities is identified with the concept of an investment project since the overwhelming majority of modern projects require the attraction of investment flows. From this point of view, a project (investment project) is a package of investments and related activities that accompany the project from its idea to achieving the specified performance indicators and include preinvestment, investment, operational and liquidation stages of its implementation.

Investments for the project are characterized by the focus on achieving the projected result; limited financial and other types of resources; the presence of certain external conditions of functioning, which form the conditions of risk and uncertainty; the interconnectedness of the processes of investing resources (financial, intellectual, etc.) and obtaining results.

The main stages of the investment phase of the project: establishing the legal, financial, organizational framework for the implementation of the project; preparation and conducting of tenders; engineering and engineering design; acquisition and transfer of technology; acquisition of land, construction work and installation of equipment; product marketing and more.

A life cycle is a concept that considers a project as a logical sequence of phases, stages, and stages of functioning with its timeframes. Development of the project from the idea, setting goals and objectives for its full implementation includes such important activities as planning, resource modeling, expertise, detailed design, description of functional aspects (marketing, technical, institutional, social, financial, risk analysis), investment, implementation project, monitoring (evaluating the effectiveness of the selected strategy) and others related to the specific project specifics.

An important functional aspect of project analysis is marketing analysis. The result of the designer's activity is a product in quantitative, qualitative, aesthetic, ergonomic, environmental and other aspects of measurement. The task of marketing analysis is an analysis of the market environment:

- The research of demand for goods, products or services;

- Estimating the size of a potential market and creating efficient goods and services;

- Identification of factors influencing the process of product sales; 
- The definition of causal relationships between the benefits of consumers from the purchase of goods with the needs and interests of the consumer;

- Identification of the reasons for the decrease of demand, means of reducing the demand fluctuation with the help of flexible prices, stimulating demand, improving the quality of goods, analysis of operational qualities.

Understanding this, leading design schools around the world are trying to make environmental activities an integral part of the project. The quality of the product already at the project stage should be considered as an ecological category.

In the process of studying the discipline "Organization of project activity" at KNUC\&A during the master's degree (5 year, 120 years), the field of knowledge "Art", future specialists consider the project as a unique set of coordinated works of a given content with a defined life cycle, an alternative cost of resources that aimed at achieving the goals in the characteristics of duration and cost. By forming the concept of a project as a sequence of phases, stages, each of which has its name and time limits, future designers are developing a proposal (idea) of a new project, which, after a feasibility study, can turn into innovation.

Future experts, using methodological approaches and scientific and practical tools, analyze the viability of the project; predict the effectiveness of the project, determine its value, comparing the qualitative and quantitative costs and benefits that will be gained as a result of its implementation; simulate alternative cost; carry out analysis of break-even, payback period of the project; predict possible cash flows; carrying out an institutional analysis of external factors influencing the course of the process, carry out risk analysis.

Any project cannot exist without taking into account factors of the external environment. To date, the system approach is an integrative method of problem-setting and problem-solving. From the point of modern science view, human activity and the world around us have systemic character (structuring, interconnection, etc.). Future designers consider the object as a model of the system (principles of interconnection, multiplicity, multidimensionality, hierarchy of heterogeneity, dynamism, etc.) taking into account financial, political, economic, environmental, social, scientific and technical, cultural, natural, legal and other factors, which influence the successful implementation of the project, the stable operation of the enterprise, design studio, etc. As a result of studying the course, future specialists will present a structured description of the project, its development. Tasks include: Organization of an enterprise or institution in terms of methodology and tools of project analysis; Carrying out an analysis of the activity of a certain enterprise or institution (one or two in the comparative analysis) from the point of view of the methodology and project analysis toolkit; Business game - to develop and present the business plan of the project (start of business with the production of products or services, in particular, the socio-cultural sphere of activity, construction, modernization of production, Internet technologies, start-up, etc.) for potential investors, with conviction of expediency of investment.

The results of the survey conducted by masters on the perception of the essence and distribution of key characteristics of the project before and after the study course "Organization of the project activity" showed the expediency of taking into account the main features of the project during the master's training.

Conclusions. During the study of the discipline "Organization of project activity", future architects and designers, developing an architectural design project from the concept, ideas to its successful implementation, provide a systematic link between the fundamental theoretical training of students and their practical activities in the current market conditions of life. Applying the principles of an integrated approach to Architectural Graphic Design with using the toolkit for project analysis in its own project activities and having professional competencies, future specialists will become the most demanded and competitive on the modern labor market.

1. Андреев А. А. Педагогика высшей школы. Новый курс. Москва: Московский международный институт эконометри-

2. Harberger A.C. and Jenkins G.P. Cost-Benefit Analysis of Investment Decisions. Harvard Institute for International ки, инфрорматики, финансов и права, 2002. 264 с.

Development, Cambridge, Massachusetts.1998. 330p. 1982. $224 \mathrm{c}$

3. Бархин Б.Г. Методика архитектурного проектирования: Учеб.-метод. пособие для вузов. Москва: Стройиздат, $1999,415 \mathrm{c}$.

4. Яковлєв М. І. Геометричні принципи художнього формотворення: дис. ... доктора технічних наук: 05.01.03. Київ,

5. Ковальов Ю.М., Гірник Н.О. Забезпечення психологічного комфорту при проектуванні житла на основі теорії самоорганізації С-простору: Праці Таврійського державного агротехнологічного ун-ту. Мелітополь, 2010. С. 58-67.

6. Нові технології навчання: навч.-метод. зб. / під ред. В.О. Зайчук. К.: Інститут змісту і методів навчання, 1996. 176 с.

7. Липсиц И.В. Инвестиционный проект: методы подготовки и анализа. Москва: Изд-во БЕК, 1996. 304с.

8. Ізбаш С.С. Проектна діяльність як фрактор соціально-професійної адаптації студентів педагогічного університету: дис. ... канд. пед. наук: 13.00.04. Київ, 2007, 204 с.

9. Осмоловський А. Від навчального проекту до соціальної самореалізації особистості. Шлях освіти. 2000. №2. С.34-

37.

10. Мейер Маршал В. Оценка эффективности бизнеса. Москва: ООО «Вершина», 2014. 272 с.

11. Проблеми та перспективи розвитку інноваційної діяльності в Україні: матеріали IX Міжнар. бізнес-форуму (Київ, 17 берез. 2016 р.). Київ, 2016. 192 с.

\section{References}

1. Andreev A. A. (2002). Higher School Pedagogy. New course. Moscow: International institute of econometrics, informatics, finance and law [in Russian]. 
2. Harberger A.C. and Jenkins G.P. (1998). Cost-Benefit Analysis of Investment Decisions, Harvard Institute for International Development, Cambridge, Massachusetts [in English].

3. Barkhin B.G. (1982). Method of architectural designing. Moscow: Stroyizdat [in Russian].

4. Yakovlev M.I. (1999). Geometrical principles of artistic shaping. Doctor's thesis. Kiev: KNUBA [in Ukrainian]

5. Kovalev Yu.M. \& Hirnyk N.O. (2010). Providing psychological comfort when designing housing on the basis of the theory of self-organization of the C-space. Proceedings of the Tavria state agrotechnical university Vip.4. Applied geometry and others. schedule. (Vols. 1), (pp. 58-67). Melitopol: TDATU [in Ukrainian]

6. Zaychuk V.O. (Eds.). (1996). New teaching technologies: teaching method. Ksev: Institute of Content and Methods of Education [in Ukrainian]

7. Lipsits I.V. (1996). Investment project: methods of preparation and analysis. Moscow: BEK [in Russian].

8. Izbash S.S. (2007) Project activity as a factor of social-professional adaptation of students of the pedagogical university. Candidate's thesis. Kiev: MDPU [in Ukrainian]. [in Ukrainian].

9. Osmolovsky A. \& Vasilenko L. (2000) From the educational project to the social self-realization of the individual, 2, 34-37

10. Meyer Marshall B. (2014). Evaluation of business efficiency. (A.O. Korsunsky, Trans). Moscow: "Vershina [in Russian].

11. Mazarak A.A. (2016). Problems and prospects of development of innovation activity in Ukraine: materials of IX Intern. Business forum (Kyiv, 17 March 2016). Kiev: KNTEU [in Ukrainian].

Стаття надійшла до редакції 16.10.2018 p.

УДК 792.8

\author{
Бойко Ольга Степанівна \\ кандидат мистецтвознавства, доцент, \\ доцент кафедри хореографічного мистецтва \\ Київського національного університету \\ культури і мистецтв \\ ORCID 0000-0001-4534-2201 \\ boykoolgast@ukr.net
}

\title{
ХОРЕОГРАФІЯ У НОМЕРІ ЕСТРАДНОГО ВОКАЛІСТА
}

Мета дослідження - виявити особливості хореографії у номері естрадного вокаліста. Методологія. Систематизація підходів до розуміння місця та ролі хореографії у номері естрадного вокаліста шляхом аналізу наукової та методичної літератури дало змогу провести науково об'єктивне дослідження. Наукова новизна полягає в обґрунтуванні необхідності різноаспектної хореографічної підготовки естрадних артистів-вокалістів задля високоякісного втілення художнього образу в діапазоні від сольного номера до мюзиклу. Висновки. Хореографрічна складова номера естрадного вокаліста виконує не лише суто візуальну, прикрашальну функцію, а й сприяє поглибленню художнього образу, урізноманітненню його сприйняття глядачем. У системі підготовки естрадного співака вдосконалення вокальних можливостей повинне йти паралельно з хореографічною підготовкою 3 урахуванням домінантності вокального мистецтва в номері. Хореографічна підготовка вокалістів потрібна для вільного пластичного та танцювального імпровізування, виконання поставлених режисером та балетмейстером танцювальних композицій, органічної взаємодії із балетом-супроводом на сцені. Підготовка артиста мюзиклу, де хореографрія наближається за кількісним та якісним параметрами до домінантного вокального мистецтва, вимагає розробки спеціальних тренувальних методик, що синхронізують вокал та хореографію. Поліваріантність підходів до хореографічної складової номерів естрадних солістів-вокалістів дає можливість найоптимальніше реалізувати художній образ відповідно до мистецьких завдань та індивідуальних особливостей артиста

Ключові слова: хореографія; естрадний вокал; естрадний номер; артист-вокаліст; танець.

Бойко Ольга Степановна, кандидат искусствоведения, доцент, доцент кафедры хореографического искусства Киевского национального университета культуры и искусств

Хореография в номере эстрадного вокалиста

Цель исследования - выявить особенности хореографии в номере эстрадного вокалиста. Методология. Систематизация подходов к пониманию места и роли хореографии в номере эстрадного вокалиста путем анализа научной и методической литературы позволило провести научно объективное исследование. Научная новизна заключается в обосновании необходимости разноаспектной хореографической подготовки эстрадных артистов вокалистов для высококачественного воплощения художественного образа в диапазоне от сольного номера до мюзикла. Выводы. Хореографическая составляющая номера эстрадного вокалиста выполняет не только чисто визуальную декоративную функцию, но и способствует углублению художественного образа, разнообразия его восприятия зрителем. В системе подготовки эстрадного певца совершенствование вокальных возможностей должно идти параллельно с хореографической подготовкой с учетом доминантности вокального искусства в номере. Хореографическая подготовка вокалистов нужна для свободного пластического и танцевального импровизирования, выполнения поставленных режиссером и балетмейстером танцевальных композиций, органичного взаимодействия с балетом-сопровождением на сцене. Подготовка артиста мюзикла, где хореография приближается по количественным и качественным параметрам к доминантному вокальному искусству, требует разработки специальных тренировочных методик, синхронизирующих вокал и хореографию. Поливариантность подходов к хореографической составляющей номеров эстрадных солистов-вокалистов дает возможность оптимально реализовать художественный образ в соответствии с художественными задачами и индивидуальными особенностями артиста.

Ключевые слова: хореография; эстрадный вокал; эстрадный номер; артист вокалист; танец.

Boiko Olha, Candidate of Arts, Associate Professor, Associate Professor of the Department of Choreographic Art of Kyiv National University of Culture and Arts

Choreography in the performance of a pop vocalist

Purpose of the article is to identify the characteristics of choreography in the pop vocalist number. Methodology. Systematization of approaches to understanding the place and role of choreography in the pop vocalist number by analyzing the scientific and

(C) Бойко О. С., 2019 